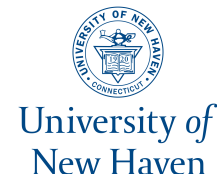

American Business Review

Volume 18 | Number 2

Article 3

$6-2000$

\title{
The Determinants of Capital Structure
}

Follow this and additional works at: https://digitalcommons.newhaven.edu/americanbusinessreview

\section{Recommended Citation}

(2000) "The Determinants of Capital Structure," American Business Review. Vol. 18 : No. 2 , Article 3.

Available at: https://digitalcommons.newhaven.edu/americanbusinessreview/vol18/iss2/3 


\section{The Determinants of Capital Structure}

Arvin Ghosh, Francis Cai and Wenhui Li

\section{OBJECTIVES}

This paper attempts to analyze the important determinants of capital structure in the U.S. manufacturing industries. Our study extends the empirical works on the determinants of capital structure in three ways. First, apart from taking all the relevant independent variables as determinants, it sheds new light on the relationship between business risk and leverage. ${ }^{1}$ Second, it shows rather insignificant role of industry dummies as a proxy for industry characteristics in capital structure determination. Third, it uses both the data-sets of Compustat and Fortune 500 largest firms in analyzing the determinants of capital structure, not attempted before.

\section{BACKGROUND}

Ever since Stewart Myers' article on the determinants of corporate borrowing (JFE, 1977), literature on the determinants of capital structure has grown steadily. Sheridan Titman and Roberto Wessels' article on the determinants of capital structure choice $(J F, 1988)$ took such attributes of firms as asset structure, non-debt tax shields, growth, uniqueness, industry classification, size, earnings, volatility and profitability, but found only uniqueness (characterized by the firm's expenditure on research and development, selling expenses, and the rate at which employees voluntarily leave their jobs) was highly significant. But Harris and Raviv $(J F, 1991)$ in their seminal article on the subject point out that the consensus among the financial economists is that leverageincreases with fixed costs, nondebt tax shields, investment opportunities and firm size, and decreases with volatility, advertising expenditure, the probability of bankruptcy, profitability and uniqueness of the product.

In a more recent article, Rajan and Zingales (JF, Dec. 1995) took asset structure, investment opportunities, firm size and profitability as the determinants of capital structure. They found that leverage increases with asset structure and size, butdecreases with growth opportunities and profitability. However, in an earlier article (1991), Kale, Noe and Ramirez took nondebt tax shields, firm size, and business risk (i.e., volatility of cash flows) as the cross-sectional determinants of capital structure and had found that nondebt tax shields and firm size had positive signs, but business risk was decreasing first and then increasing with the optimal debt level.

For our tests of the determinants of capital structure, we have taken asset size, growth of assets, nondebt tax shields, fixed asset ratio, profit margin, research and development expenditure, advertising expenditure, selling expenses, and the coefficient of variation of cash flows as business risk (volatility). We have also run the tests with and without business risk to see the change of signs and robustness of the test results. Further, we have used the dummy variables for industry classification to see whether industry characteristics have any impact on the capital structure.

Dr. Arvin Ghosh is Professor of Economics and Finance, William Paterson University, Wayne, New Jersey. He has published numerous articles in academic journals and is the author of several books.

Dr. Francis Cai is Associate Professor of Finance, William Paterson University, Wayne, New Jersey. He has published in such journals as Journal of Multinational Finance and Accounting and Business Review.

Dr. Wenhui Li is Assistant Professor, Center for Business and Government, Baruch College, City University of New York. 


\section{DATA SOURCE AND METHODOLOGY}

We have used the Compustat file for the data source. Our sample was composed of 362 firms, divided into 19 industries. We have selected two years - 1982 and 1992 - for our cross-sectional studies. We have also tried to pool the cross-section data into time series covering 1982-1992, but without any success. ${ }^{2}$

However, we did try to delve into Fortune magazine's list of the largest 500 manufacturing companies to see whether the results obtained by the Compustat files are corroborated by the Fortune 500 data set. ${ }^{3}$ For that, our sample was composed of 256 surviving firms, divided into 21 industries covering 1974-1992. The results were mixed as explained in Table 7.

As for methodology, we have used the ordinary least square (OLS) equations, with the long-term debt ratio (Long-term Debt/ Total Assets) as the dependent variable, and asset size, growth of assets, non-debt tax shields (depreciation allowance and investment tax credit), fixed assets-to- total assets ratio, net profit margin, research and development expenditure(\%), advertising expenditure $(\%)$, and selling expenses $(\%)$ as independent variables. For business risk (i.e., volatility) as an independent variable, we have taken the coefficient of variation of cash flows.

In order to test the relationship between capital structure and its determinants, we estimate the following multiple regression equation for our sample: ${ }^{4}$

$$
\begin{aligned}
& \mathrm{Y}=\beta_{0}+\beta_{1} \mathrm{AS}+\beta_{2} \mathrm{GA}+\beta_{3} \mathrm{NDTS}+\beta_{4} \mathrm{RFATA}+\beta_{5} \mathrm{NPM} \\
& +\beta_{6} \mathrm{RD}+\beta_{7} \mathrm{ADV}+\beta_{8} \mathrm{SE}+\beta_{9} \mathrm{CVCF}+\beta_{10} \mathrm{CVCF}^{2}+\varepsilon
\end{aligned}
$$

where

$$
\begin{aligned}
\mathrm{Y} & =\text { Long Term Debt } / \text { Total Assets; } \\
\mathrm{AS} & =\text { Asset Size; } \\
\mathrm{GA}= & \text { Growth of Assets; } \\
\text { NDTS }= & \text { Non-debt Tax Shield; } \\
\text { FATA }= & \text { Fixed Assets/total Assets; } \\
\mathrm{NPM}= & \text { Net Profit Margin; } \\
\mathrm{RD}= & \text { Research and Development Expenditure } \\
& (\%) ; \\
\text { ADV }= & \text { Advertising Expenditure }(\%) ; \\
\mathrm{SE} & =\text { Selling Expense }(\%) ; \\
\mathrm{CV}= & \text { Coefficient of Variation of Cash Flows. }
\end{aligned}
$$

When we include the industry dummies as explanatory variables, the equation becomes:

$$
\begin{aligned}
& \mathrm{Y}=\beta_{0}+\beta_{1} \mathrm{AS}+\beta_{2} \mathrm{GA}+\beta_{3} \mathrm{NDTS}+\beta_{4} \mathrm{RFATA}+\beta_{5} \mathrm{NPM} \\
& +\beta_{6} \mathrm{RD}+\beta_{7} \mathrm{ADV}+\beta_{8} \mathrm{SE}+\beta_{9} \mathrm{CVCF}+\beta_{10} \mathrm{CVCF}^{2} \\
& +\beta_{11} \mathrm{D}_{1}+\beta_{12} \mathrm{D}_{2}+\ldots+\beta_{18} \mathrm{D}_{18}+\varepsilon
\end{aligned}
$$

where $D_{1}$ through $D_{18}$ are industry dummy variables.

Following the capital structure theory, we would expect the signs of $\beta_{1^{\prime}}, \beta_{3}$, and $\beta_{4}$ to be positive, and the signs of $\beta_{2}, \beta_{5^{\prime}}, \beta_{6^{\prime}}, \beta_{7}$ and $\beta_{8}$ to be negative. As for $\beta_{9}$ and $\beta_{10}$ the relationship is expected to be first positive and then negative, according to the traditional capital structure theory. The results are shown in Table 1 through 7.

\section{THE RESULTS}

In Table 1, we have shown the regression results for the year 1992. We find that only the growth of assets, fixed asset ratio, and the $R \&$ D expenditure(\%) had significant $t$-values at the 1 percent level.

TABLE 1

Capital Structure Determinants-- 1992

(Long Term Debt Ratio as Dependent Variable)

\begin{tabular}{lcc}
\hline Independent Variable & b-coefficient & T-value \\
\hline Asset & 0.0000492 & 0.370000000 \\
Growth of Assets & -0.1979850 & $-3.158000000^{* *}$ \\
Depreciation & -0.0021442 & -0.591000000 \\
Investment Tax Credit & 0.0308000 & 0.362000000 \\
Fixed Asset Ratio & 0.0811000 & $2.780000000^{* *}$ \\
Profit Margin & -0.0808000 & -1.042000000 \\
R\&d Expenditure (\%) & -0.8678000 & $-2.842000000^{* *}$ \\
Advertising Exp. (\%) & 0.0452000 & 0.121000000 \\
Selling Exp. (\%) & -0.0012929 & -0.015000000 \\
Adj. $\mathbf{R}^{2}$ & 0.0899 & \\
\hline
\end{tabular}

* --significance at $5 \%$ Level

**--significance at $1 \%$ Level

The negative sign of the $b$-coefficient for the growth of assets conforms with the conclusion reached by Harris and Raviv, as firms expecting high future growth use a greater amount of equity finance. As for the fixed asset ratio (fixed assets/ total assets), its contribution was very small, although the positive sign means the increase of fixed assets has a collateral value for higher debt. But the negative sign of the $b$ coefficient for $\mathrm{R} \& \mathrm{D}$ expenditure indicates that firm leverage increases with the decrease in $R \& D$ expenditure, again confirming the conclusion reached by Harris and Raviv.

Table 2 shows the regression results for the year 1982. Here we find that the growth of assets was not significant. But the fixed asset ratio was significant at the 1 percent level, as were $R$ \& D expenditure and the advertising expenditure. The profit margin was also significant at the 5 percent level. The negative signs of the latter three variables were conformed with the conclusion made by Harris and Raviv.

Tables 3 and 4 show the results of capital structure determinants with risk (a quadratic relationship with CVCF, i.e., the coefficient of variation of cash flows). Although the b-coefficients for COCF1 and COCF2 were not significant at any level in Table 3 , they were significant at the 0.05 percent level in Table 4 . Whereas 
TABLE 2

Capital Structure Determinants --1982

(Long Term Debt Ratio as Dependent Variable)

\begin{tabular}{lcc} 
Independent Variable & b-Coefficient & T-Value \\
& & \\
Asset & -0.0002472 & -0.698000000 \\
Growth of Assets & 4.4247000 & 1.563000000 \\
Depreciation & 0.0013872 & 0.282000000 \\
Investment Tax Credit & -0.0192000 & -0.422000000 \\
Fixed Asset Ratio & 0.0837000 & $3.450000000^{* *}$ \\
Profit Margain & -0.0710000 & $-1.663000000^{*}$ \\
R\&D Expenditure (\%) & -0.9771000 & $-5.417000000^{* *}$ \\
Advertising Exp. (\%) & -0.5700000 & $-2.660000000^{* *}$ \\
Selling Exp. (\%) & 0.0949000 & 1.620000000 \\
& & \\
Adj. ${ }^{2}$ & 0.1558 & \\
\hline
\end{tabular}

* --Significance at $5 \%$ level

**--Significance at $1 \%$ level

TABLE 3

Capital Structure Determinants with Risk--1992 (Long Term Debt Ratio as Dependent Variable)

\begin{tabular}{lcc}
\hline Independent Variable & b-Coefficient & \multicolumn{1}{c}{ T-Value } \\
\hline COCF1 & 27.2036000 & 0.890000000 \\
COCF2 & -4.3020000 & -0.819000000 \\
Asset & 0.0000347 & 0.261000000 \\
Growth of Assets & -19.2271000 & $-3.065000000 * *$ \\
Depreciation & -0.0013179 & -0.360000000 \\
Investment Tax Credit & 0.0129000 & 0.150000000 \\
Fixed Asset Ratio & 0.0898000 & $3.033000000^{* *}$ \\
Profit Margin & -0.0940000 & -1.205000000 \\
R\&d Expenditure (\%) & -0.8702000 & $-2.851000000^{* *}$ \\
Advertising Exp. (\%) & 0.0384000 & 0.103000000 \\
Selling Exp. (\%) & -0.0132000 & -0.157000000 \\
& & \\
Adj. R & & \\
\hline
\end{tabular}

* --significance at $5 \%$ Level

**--significance at $1 \%$ Level

Kale, Noe and Ramirez found the relationship between business risk and leverage to be quadraticfirst decreasing and then increasing, we have found it to be the opposite - first increasing and then decreasing. This conforms with the traditional theory which suggests that when risk is low, higher will be the debt level, but with higher risk, debt level should be lower.

In Tables 3 and 4 , both the variables depicting growth of assets and fixed asset ratios were significant, along with the variable for $R$ \& D expenditure. In Table 4, however, advertising expenditure was also significant at the 1 percent level. The negative signs for both $R$ \& $D$ expenditure and advertising expenditure conform with the conclusions reached by Harris and Raviv.

Tables 5 and 6 show the b-coefficients of the nine capital structure determinants with risk and industry dummy variables for 1992 and 1982. Here, again, the growth of assets, fixed asset ratio, and $R$ \& $D$ expenditure were significant at the 1 percent level in Table 5. But the growth of assets variable was not significant in Table 6. Similarly, advertising expenditure variable was not significant in Table 5 but was significant at the 1 percent level in Table 6.
TABLE 4

Capital Structure Determinants with Risk--1982 (Long Term Debt Ratio as Dependent Variable)

\begin{tabular}{lcc}
\hline Independent Variable & b-Coefficient & T-Value \\
\hline COCF1 & 26.0692000 & $1.817000000^{*}$ \\
COCF2 & -4.5022000 & $-1.817000000^{*}$ \\
Asset & -0.0002313 & -0.649000000 \\
Growth of Assets & 4.6838000 & $1.654000000^{*}$ \\
Depreciation & 0.0011917 & 0.240000000 \\
Investment Tax Credit & -0.0182000 & -0.401000000 \\
Fixed Asset Ratio & 0.0839000 & $3.450000000^{* *}$ \\
Profit Margain & -0.0704000 & -1.638000000 \\
R\&D Expenditure (\%) & -0.9690000 & $-5.376000000^{* *}$ \\
Advertising Exp. (\%) & -0.5621000 & $-2.624000000^{* *}$ \\
Selling Exp. (\%) & 0.0938000 & 1.588000000
\end{tabular}

Adj. $\mathbf{R}^{2}$

0.1053

* --Significance at $5 \%$ level

**--Significance at $1 \%$ level

TABLE 5

Capital Structure Determinants with Risk and Industry Dummy Variables -- 1992 (Long Term Debt Ratio as Dependent Variable)

\begin{tabular}{lcc}
\hline Independent Variable & b-Coefficient & \multicolumn{1}{c}{ T-Value } \\
\hline COCF1 & -19.4276000 & -0.477000000 \\
COCF2 & 2.5560000 & 0.384000000 \\
Asset & 0.0000082 & 0.061000000 \\
Growth of Assets & -20.5498000 & $-3.266000000^{* *}$ \\
Depreciation & 0.0001237 & 0.032000000 \\
Investment Tax Credit & -0.0133000 & -0.152000000 \\
Fixed Asset Ratio & 0.0993000 & $3.311000000^{* *}$ \\
Profit Margin & -0.0969000 & -1.242000000 \\
R\&D Expenditure (\%) & -0.8093000 & $-2.646000000^{* *}$ \\
Advertising Exp. (\%) & 0.0524000 & 0.140000000 \\
Selling Exp. (\%) & -0.0299000 & -0.355000000 \\
Dummy Variables & \multicolumn{2}{c}{7 Negative } \\
& 1 positive \\
& 10 zero
\end{tabular}

Adj. $\mathbf{R}^{2}$

0.1175

* --Significance at $5 \%$ level

**-_Significance at $1 \%$ level

TABLE 6

Capital Structure Determinants with Risk and Industry Dummy Variables --1982 (Long Term Debt Ratio as Dependent Variable)

\begin{tabular}{lcc}
\hline Independent Variable & $\beta$-Coefficient & T-Value \\
\hline COCF1 & 19.2734000 & 1.176000000 \\
COCF2 & -3.5160000 & -1.251000000 \\
Asset & -0.0001286 & -0.349000000 \\
Growth of Assets & 4.5182000 & 1.585000000 \\
Depreciation & -0.0002519 & -0.050000000 \\
Investment Tax Credit & -0.0086079 & -0.187000000 \\
Fixed Asset Ratio & 0.0831000 & $.370000000^{* *}$ \\
Profit Margin & -0.0707000 & -1.640000000 \\
R\&D Expenditure (\%) & -0.9400000 & $-5.161000000^{* *}$ \\
Advertising Exp. (\%) & -0.5758000 & $-2.683000000^{* *}$ \\
Selling Exp. (\%) & 0.0879000 & 1.476000000 \\
Dummy Variables & \multicolumn{2}{c}{2 Positive } \\
\multicolumn{3}{c}{ 6 Negative } \\
& 10 Zero
\end{tabular}

Adj. $\mathbf{R}^{2}$ 0.0890

*..-Significance at $5 \%$ level, **--Significance at $1 \%$ level 
When we include the dummy variables as proxy for industry characteristics, as done in Tables 5 and 6 , we have found that only 1 and 2 industries had positive signs for 1992 and 1982, respectively, while 7 and 6 had negative signs for the two selected years, respectively. Our results thus conform with that of Kale, Noe and Ramirez in this regard who had found only 3 industry dummies having positive signs, while 12 had negative signs.

In Table 7, we have used the Fortune 500 data for the year 1992 where the independent variables were

TABLE 7

Capital Structure Determinants with Risk --1992 (Using FORTUNE 500 Data)

(Long Term Debt Ratio as Dependent Variable)

\begin{tabular}{lcl}
\hline Independent Variable & b-Coefficient & T-Value \\
\hline COCF1 & 38.6012 & 0.1556 \\
COCF2 & -13.73 & -0.0476 \\
Asset & 0.000327 & $9.39205^{* *}$ \\
Growth of Assets & 3.2329 & 0.1151 \\
Depreciation & -0.0064623 & 0.00002 \\
Investment Tax Credit & -0.01570 & 0.00000 \\
& & \\
Adj. $\mathbf{R}^{2}$ & 0.0054 & \\
\hline
\end{tabular}

* --Significance at $5 \%$ level

**.-Significance at $1 \%$ level six, instead of nine. ${ }^{4}$ Here only the asset size was significant at the 1 percent level. But the signs of COCF1 and COCF2 were significant - first positive and the negative. This conforms with the earlier results we have obtained in Tables 3 and 4, respectively.

\section{CONCLUSIONS}

Our results thus confirm the usefulness of taking growth of assets, fixed asset ratio, $R$ \& $D$ expenditure and advertising expenditure as the determinants of capital structure. At the same time, our results show that the relationship between business risk and leverage is quadratic, and it is first increasing and then decreasing - a relationship more close to the traditional theory and contradicts the results obtained by Kale, Noe and Ramirez. But the problem of omitted variables remains as the known determinants 'explain' a very small percentage of the variation in capital structure. All this indicates that nothing is "settled" in the area of the determinants of capital structure, and much work is to be done if we want to understand what truly determine the capital structure of a firm or an industry.

\section{NOTES}

1. We like to state that our study had shown the exact opposite relation of what Kale et al got in their study. We have found that the relationship between business risk and financial leverage, although quadratic, was first increasing and then decreasing, just the opposite of the finding of Kale, Noe and Ramirez. Our result in this respect confirms the traditional hypothesis which suggests that when risk is low higher will be the debt level, but with higher risk, debt level should be lower.

2. We have taken 1982 and 1992 because the Compustat data go back to 20 years (when we started our research in 1994, the data set we had obtained was from 1972 to 1992). We took the 10-year period because we thought that the 10-year period was enough to explain the capital structure determinants. These were the annual data given by the Compustat. We may, in future, take the quarterly data to see whether they conform to the results obtained by using annual data..

3. The main reason we had taken the FORTUNE 500 companies was to see whether the results would vary with a widely-used data-set. We found the results were the same, more or less.

4. We have taken nine independent variables in our regression models because they are the relevant variables to explain the capital structure of a firm as found in finance literature.

\section{REFERENCES}

Harris M. and Raviv R., "The Theory of Capital Structure," Journal of Finance, March 1991, pp. 297-356.

Kale, J.R., Noe, T.H., and Ramirez, G.G., "Cross-Sectional Determinants of Capital Structure: Theory and Evidence," (Working Paper), Jan. 1988.

Kale, J.R., Noe, T.H., and Ramirez, G.G., "The Effect of Business Risk on Corporate Capital Structure: Theory and Evidence," Journal of Finance, Dec. 1991, pp. 1693-1715.

Myers, S., "Determinants of Corporate Borrowing," Journal of Financial Economics, Nov. 1977, pp. 147-76.

Rajan R.G. and Zingales, L., "What Do We Know about Capital Structure? Some Evidence from International Data," Journal of Finance, Dec. 1995, pp. 1421-59.

Titman S. and Wessels R., "The Determinants of Capital Structure Choice," Journal of Finance, March 1988, pp. 1-19. 